\title{
PELATIHAN MANAJEMEN PENYELENGGARAAN TURNAMEN BOLA VOLI ANTAR PELAJAR SMA/SMK SEKABUPATEN NGADA- NAGEKEO BAGI MAHASISWA PJKR STKIP CITRA BAKTI
}

\author{
Yohanes Bayo Ola Tapo"1), Robertus Lili Bile ${ }^{2)}$ \\ 1,2)Pendidikan Jasmani Kesehatan \& Rekreasi, \\ 1,2)Sekolah Tinggi Keguruan dan IImu Pendidikan Citra Bakti \\ 1)yohanesbayoolatapo@gmail.com, 2)robertkleden@gmail.com
}

\section{Histori artikel}

Received:

20 Maret

Accepted:

10 April 2020

Published:

15 April 2020

\begin{abstract}
Abstrak
Kegiatan Pengabdian Kepada Masyarakat (PKM) ini bertujuan untuk memberikan pemahaman dan keterampilan yang mendalam kepada para mahasiswa PJKR STKIP Citra Bakti tentang manajemen penyelenggaraan turnamen bola voli yang baik dan benar mulai dari pembentukan kepanitiaan, pelaksanaan kegiatan persiapan, dan pelaksanaan kegiatan turnamen yang meliputi; 1) kegiatan mengundang tim, 2) kegiatan technical meeting (TM), yang terdiri dari: (a) pembagian grup, (b) penyusunan jadwal pertandingan, dan (c) pembuatan peraturan pertandingan, 3) pelaksanaan kegiatan pertandingan, yang terdiri dari: (a) kegiatan rapat koordinasi setiap pertandingan, (b) pengawasan pertandingan, (c) perekapan hasil dan (5) perhitungan nilai tim. Adapun mahasiswa yang menjadi target utama dalam kegiatan ini adalah mahasiswa/mahasiswi PJKR yang berada pada semester III dan V. Metode pelaksanaan kegiatan pengabdian ini dilaksanakan dengan memberikan kesempatan kepada mahasiswa untuk terlibat langsung dalam semua kegiatan dengan bimbingan dan arahan dalam praktik yang dilakukan oleh tim pengabdi. Hasil dari kegiatan ini adalah mahasiswa memiliki gambaran yang jelas dan pengelaman nyata guna meningkatkan pemahaman dan keterampilan sebagai follow-up dari materi perkuliahan yang telah dipelajari dalam memanajemen sebuah kegiatan turnamen bola voli yang baik dan benar.
\end{abstract}

Kata-kata Kunci: manajemen turnamen, pertandingan bola voli 
Abstract. This community service aims to provide understanding and skills to the PJKR STKIP Citra Bakti students about the proper and correct management of volleyball tournaments from the formation of the committee, the implementation of preparatory activities, and the implementation of tournament activities which include; 1) activities invite teams, 2) technical meeting (TM) activities, consisting of (a) division of Tim groups, (b) preparation of match schedules, and (c) making competition rules, 3) the implementation of competition activities, consisting of (a) coordinating meeting activities for each match, (b) match monitoring, (c) recording of results and (5) calculation of team scores. The students as the main target in this activity are PJKR students in semester III and V. The method of activities is carried out by providing opportunities for students to be directly involved in all activities with guidance and direction in practice carried out by the team. The results of this activity are students have a clear picture and real experience to improve understanding and skills as a follow-up of lecture material that has been learned in managing a good and correct volleyball tournament activity.

Keywords: Management, Tournament, Match, Volleyball.

\section{PENDAHULUAN}

Pertandingan bola voli merupakan salah satu even olahraga yang cukup populer di kalangan masyarakat dan menjadi tontonan yang sangat menghibur karena berbagai aktivitas dalam olahraga bola voli sangat aktraktif. Hal ini senada dengan Fédération Internationale de Volleyball (FIVB) dalam Official Volleyball Rules 2017-2020 dalam Tapo (2019: 21) yang menjelaskan bahwa Bola voli adalah salah satu olahraga kompetitif dan rekreasi paling sukses dan populer di dunia. Permainan yang cepat (fast), menyenangkan (exciting), aksi yang meledak (explosive) dan terdiri dari beberapa elemen yang interaktif yang menjadikannya unik di antara permainan reli (rally) lainnya. Hal ini akan dicapai jika turanamen bola voli dapat diselenggarakan dengan sebuah manajemen pertandingan yang baik dan mengedepankan peraturan dan layanan pertandingan yang standar.

Pemahaman dan keterampilan memanajemen sebuah kegiatan turnamen olahraga merupakan salah satu kompetensi dasar yang seyogyanya harus dimiliki oleh setiap mahasiswa/i olahraga sebagai salah satu nilai jual pada dunia kerja nantinya. Konsep ini senada dengan hasil kajian yang dikemukakan oleh Brown, Willet, Goldfine, \& Goldfine (2018) bahwa pada prinsipnya besar kecilnya pengalaman berkaitan dengan kesempatan yang diperoleh mahasiswa baik praktis maupun terapan selama studi, akan banyak berkontribusi dalam memperoleh peluang kerja setelah lulus. Pendapat lain yang dikemukakan oleh Hartmann \& Kwauk (2011) menjelaskan bahwa Dalam konteks peningkatan kapasitas diri, pendidikan, bimbingan, pelatihan keterampilan, dan intervensi langsung harus menjadi pusat daripada program olahraga itu sendiri, dengan tujuan pengembangan kapasitas pemahaman teoretis serta keterampilan praktis. Oleh karena itu, upaya memberikan berbagai pengalaman bagi mahasiswa untuk memperoleh dan meningkatkan pemahaman serta keterampilan manajemen kegiatan olahraga melalui bentuk-bentuk kegiatan pelatihan sangat perlu dilakukan karena secara prinsip, aspek pemahaman dan keterampilan akan dapat dicapai dan ditingkatkan apabila mahasiswa secara langsung memiliki pengalaman nyata berkaitan dengan manajemen kegiatan atau pertandingan olahraga yang meliputi kegiatan perencanaan, pelaksanaan dan evaluasi. 
Kegiatan even atau turnamen olahraga yang memiliki kualitas penyelenggaraan yang baik dapat membawa gengsi tersendiri bagi setiap peserta sehingga memungkinakan setiap tim akan menyiapkan dan mengikuti turnamen dengan sebaik-baiknya. Selain itu penyelenggaraan kegiatan turnamen olahraga yang dikemas baik dengan mengedepankan segala proses penyelenggaraan sesuai dengan aturan-aturan resmi akan memberikan kesempatan kepada para pemain untuk belajar dan membiasakan diri dengan aturan pertandingan yang resmi, sehingga pada akahirnya dapat meningkatkan kualitas dan prestasi para pemian sebagai peserta kegiatan.

Menurut Marwan, Rahmat, \& Rohyana (2018: 180) menjelasakan bahwa berdasarkan U.U. R.I. No. 3 Tahun 2005 Tentang Sistem Keolahragaan Nasional, ada tiga ruang lingkup olahraga yang meliputi kegiatan Olahraga pendidikan, olahraga rekreasi dan olahraga prestasi, sehingga dikenal adanya manajemen olahraga pendidikan, olahraga rekreasi dan olahraga prestasi, Selanjutnya dijelasakan bahwa manajemen olahraga pendidikan diterapkan dilingkungan sekolah baik pendidikan formal, non formal maupun pada perguruan tinggi.

Sebagai sebuah Program Studi Pendidikan Olahraga, Program Studi PJKR STKIP Citra Bakti merasa perlu menghadirkan sebauh kegiatan turnamen yang dikemas secara baik sebagai upaya kongkrit Program Studi untuk memberikan wadah sebagai ruang dan tempat bagi para pelajar terkhusus tingkat SLTA di Kabupaten Ngada dan Nagekeo untuk mengaptualisasikan minat dan bakat dalam rangka mencapai prestasi olahraga.

Selain itu pelaksanaan kegiatan turnamen ini merupakan ajang yang tepat bagi mahasiswa/i PJKR STKIP Citra Bakti terkhusus Semester III dan V untuk belajar secara langsung dengan terlibat aktif didalam kepanitiaan dan komisi perwasitan. Sebagai ajang pembelajaran mahasiswa PJKR maka kegiatan turnamen ini dilaksanakan dengan manajemen pertandingan yang dikemas secara baik dan didampingi secara langsung oleh tim pengabdi untuk mengatur keterlibatan mahasiswa dalam organisasi pertandingan dan adminstrasi pertandingan melalui berbagai kegiatan mulai dari pembentukan kepanitiaan, pelaksanaan kegiatan persiapan, dan pelaksanaan kegiatan turnamen.

Menurut Firmansyah \& Hariyanto (2019: 5-7) menjelaskan bahwa pengorganisasian pertandingan harus dimulai dengan menentukan jumlah serta menyusun siapa saja panitia yang bertugas yang disesuaikan dengan kebutuhan acara, mulai dari ketua pertandingan, wakil ketua pertandingan, sekretaris, bendahara, panitia hakim (komisi disiplin), dan seksiseksi.

Selanjutnya dijelaskan juga dua hal yang perlu menjadi perhatian dalam membentuk suatu susunan kepanitian, yaitu Penugasan dan Pemilihan Petugas (Firmansyah \& Hariyanto: 2019). 
Sedangkan Administrasi Pertandingan merupakan aktivitas perencanaan dan pelaksanaan pertandingan atau perlombaan cabang-cabang olahraga, yang meliputi empat tahap penyelenggaraan pertandingan, yaitu: 1) Langkah Persiapan, 2) Menjelang Pertandingan, 3) Saat Pertandingan Berlangsung, dan 4) Sesudah Pertandingan (Firmansyah \& Hariyanto, 2019).

Hal-hal yang menyangkut dengan manajemen kegiatan pertandingan ini lah yang menjadi fokus tim pengabdi dalam mendampingi mahasiswa selama kegiatan turnamen. Adapun kegiatan manajemen turnamen yang dilaksanakan dalam kegiatan pengabdian ini adalah manajemen kegiatan turnamen bola voli putra dan putri antar pelajar SLTA - PJKR Citra Bakti Cup 1 Tahun 2020, sehingga secara umum tujuan yang menjadi fokus dalam kegiatan pengabdian ini adalah untuk memberikan pemahaman dan keterampilan yang mendalam kepada para mahasiswa PJKR STKIP Citra Bakti sebagai follow-up dari materi perkuliahan yang telah dipelajari dalam memanajemen sebuah kegiatan turnamen bola voli yang baik dan benar mulai dari pembentukan kepanitiaan, pelaksanaan kegiatan persiapan, dan pelaksanaan kegiatan turnamen yang meliputi; 1) kegiatan mengundang tim, 2) kegiatan technical meeting (TM), yang terdiri dari: (a) pembagian grup, (b) penyusunan jadwal pertandingan, dan (c) pembuatan peraturan pertandingan, 3) pelaksanaan kegiatan pertandingan, yang terdiri dari: (a) kegiatan rapat koordinasi setiap pertandingan, (b) pengawasan pertandingan, (c) perekapan hasil dan (5) perhitungan nilai tim.

Permasalahan yang menjadi fokus kajian dalam kegiatan pengabdian ini, antara lain: 1) Apakah adanya peningkatan pemahaman mahasiswa tentang kegiatan pembentukan panitia penyelengara yang baik dan benar? 2) Apakah adanya peningkatan pemahaman mahasiswa tentang pelaksanaan kegiatan persiapan kegiatan? 3) Apakah adanya peningkatan pemahaman mahasiswa tentang pelaksanaan kegiatan turnamen?

Berdasarkan fokus permasalahan yang dikaji, diharapkan kegiatan pengamdian ini dapat memberikan pemahaman dan keterampilan yang mendalam kepada para mahasiswa PJKR STKIP Citra Bakti sebagai sebuah follow-up dari materi perkuliahan yang telah dipelajari tentang manajemen penyelenggaraan turnamen bola voli yang baik dan benar mulai dari pembentukan kepanitiaan, pelaksanaan kegiatan persiapan, dan pelaksanaan kegiatan turnamen yang meliputi; 1) kegiatan mengundang tim, 2) kegiatan technical meeting (TM), yang terdiri dari: (a) pembagian grup, (b) penyusunan jadwal pertandingan, dan (c) pembuatan peraturan pertandingan, 3) pelaksanaan kegiatan pertandingan, yang terdiri dari: (a) kegiatan rapat koordinasi setiap pertandingan, (b) pengawasan pertandingan, (c) perekapan hasil dan (5) perhitungan nilai tim. 


\section{METODE PELAKSANAAN}

Adapun mahasiswa yang menjadi sasaran utama dalam kegiatan pengabdian ini lebih difokuskan pada mahasiswa/mahasiswi PJKR yang berada pada semester III dan V yang telah mendapatkan matakuliah bola voli, sehingga kegiatan pengabdian ini dapat menjadi wadah pembelajaran yang tepat sebagai aptualisasi berbagai materi perkuliahan yang telah diperoleh.

Pelaksanaan kegiatan pengabdian ini menggunakan metode pendampingan dan pelatihan. Pada metode pendampingan, mahasiswa diberi kesempatan untuk secara langsung terlibat baik sebagai perencana, pelaksana maupun evaluator kegiatan dan tim pengabdi bertugas untuk mengarahkan, sedangkan dengan metode pelatihan, mahasiswa dilatih untuk berperan secara langsung baik sebagai perangkat pertandingan misalkan sebagai wasit 1 dan wasit 2, scorer, hakim garis, ballboys, dan lain sebagainya yang berhubungan langsung dengan penyelenggaraan pertandingan secara khusus serta turnamen seca keseluruhan. Melalui kedua pendekatan dalam kegiatan ini, diharapkan mahasiswa benar-benar memiliki pengalaman nyata dalam hal memperoleh pemahaman dan keterampilan manajemen kegiatan atau turnamen olahraga.

Adapun metode pelaksanaan kegiatan pengabdian ini menggunakan metode pendampingan dan pelatihan yang dilakukan dengan memberikan kesempatan kepada mahasiswa untuk terlibat langsung dalam semua kegiatan dengan bimbingan dan arahan dalam praktik yang dilakukan oleh tim pengabdi, dengan uraian kegiatan yang dilakukan oleh tim pengabdi adalah sebagai berikut: (1) Ketua dan anggota tim pengabdi merumuskan berbagai rancangan kegiatan yang menyangkut dengan manajemen pertandingan bola voli, (2) Mahasiswa dilibatkan dalam semua proses manajemen kegiatan mulai dari tahap pembentukan panitia, tahap persiapan, dan tahap penyelenggaraan kegiatan, (3) Mahasiswa dilibatkan secara langsung dalam semua tahap evaluasi kegiatan.

Deskripsi program kegiatan pengabdian secara umum seperti pada Tabel 1.

Tabel 1. Deskripsi program kegiatan pengabdian

\begin{tabular}{|c|c|c|c|}
\hline No & Program Kegiatan & $\begin{array}{c}\text { Deskripsi Pelaksanaan Program } \\
\text { Kegiatan }\end{array}$ & $\begin{array}{l}\text { Ketercapaian } \\
\text { Program }\end{array}$ \\
\hline 1 & $\begin{array}{l}\text { Pembentukan } \\
\text { Panitia } \\
\text { Penyelengara }\end{array}$ & $\begin{array}{l}\text { Mahasiswa dilibatkan dalam } \\
\text { pembentukan panitia } \\
\text { penyelenggara, yang terdiri dari: } \\
\text { Ketua Panitia, Sekretaris, } \\
\text { Bendahara, Koordinator dan } \\
\text { Anggota Seksi: Pertandigan, } \\
\text { Perlengkapan, Acara Pembukaan } \\
\text { dan Penutupan, Usaha Dana, } \\
\text { Dokumentasi, Keamanan, }\end{array}$ & $\begin{array}{l}\text { Terbentuknya panitia } \\
\text { penyelennggara yang } \\
\text { lengkap dengan } \\
\text { pembagian tugas yang } \\
\text { jelas dengan melibatkan } \\
\text { seluruh dosen dan } \\
\text { mahasiswa PJKR. }\end{array}$ \\
\hline 2 & $\begin{array}{l}\text { Kegiatan Persiapan } \\
\text { Turnamen }\end{array}$ & $\begin{array}{l}\text { Mahasiswa dilibatkan } \\
\text { pengorganisasian kerja dan } \\
\text { pengontrolan dalam kegiatan } \\
\text { persiapan turnamen sesuai dengan } \\
\text { tugas masing-masing seksi. }\end{array}$ & $\begin{array}{l}\text { Segala kebutuhan } \\
\text { turnamen dapat } \\
\text { dipersiapkan dengan } \\
\text { lengkap dan baik. }\end{array}$ \\
\hline
\end{tabular}


3 Pelaksanaan Mahasiswa dilibatkan secara

Kegiatan Turnamen langsung dalam pelaksanaan

kegiatan turnamen mulai dari

kegiatan; 1) kegiatan mengundang

tim, 2) kegiatan technical meeting

(TM), dan 3) pelaksanaan kegiatan pertandingan.
Berbagai manajemen

kegiatan pelaksanaan

turnamen dapat

dilaksanakan dari awal

sampai akhir.

\section{HASIL DAN PEMBAHASAN}

\section{Hasil}

Kegiatan pengabdian ini dilaksanakan di Kampus STKIP Citra Bakti Ngada selama \pm 2 bulan terhitung dari bulan Januari sampai bulan Februari untuk kegiatan persiapan awal dan selama kegiatan turanmen bola voli putra dan putri antar pelajar SLTA - PJKR Citra Bakti CUP 1, yaitu selama 11 hari pertandingan dari tanggal 10 Februari sampai dengan tanggal 23 Februari 2020 dengan jeda pertandingan sebanyak 3 hari. Peserta yang terlibat dalam kegiatan pelatihan ini secara keseluruhan berjumlah 120 mahasiswa. Setiap peserta pelatihan dilibatkan secara langsung dalam setiap tahapan penyelenggaraan turnamen.

Kegiatan pelatihan yang dilakukan antara lain sebagai berikut.

Tabel 2. Kegiatan Pelatihan Manajemen Penyelenggaraan Turnamen Bola Voli

\begin{tabular}{|c|c|c|}
\hline No & $\begin{array}{c}\text { Materi } \\
\text { Kegiatan }\end{array}$ & Hasil \\
\hline 1 & $\begin{array}{l}\text { Pendampingan } \\
\text { pada tahap } \\
\text { pembentukan } \\
\text { kepanitiaan } \\
\text { turnamen }\end{array}$ & $\begin{array}{l}\text { Kegiatan diawali dengan pemilihan ketua panitia, menyusun } \\
\text { komposisi kepanitiaan, serta pembahasan job description pada } \\
\text { masing-masing seksi kerja dalam kepanitiaan. }\end{array}$ \\
\hline 2 & $\begin{array}{l}\text { Pendampingan } \\
\text { pada tahap } \\
\text { persiapan } \\
\text { pelaksanaan } \\
\text { turnamen }\end{array}$ & $\begin{array}{l}\text { Mengarahkan dan mendampingi kerja persiapan seperti } \\
\text { menyiapkan perlengkapan pertandingan, menyiapkan lapangan } \\
\text { pertandingan beserta fasilitas penunjang seperti soundsystem, } \\
\text { lampu untuk penerangan, serta menyusun rundown acara } \\
\text { pembukaan dan penutupan turnamen. }\end{array}$ \\
\hline 3 & $\begin{array}{l}\text { Pendampingan } \\
\text { penyelenggaraan } \\
\text { kegiatan turnamen }\end{array}$ & $\begin{array}{l}\text { a. Mengarahkan peserta pelatihan dalam kegiatan penyebaran } \\
\text { informasi dan undangan kepada peserta turnamen. } \\
\text { b. Mengarahkan kepanitiaan dalam kegiatan technical meeting } \\
\text { mengatur jadwal pertandingan dan penyelenggaraan } \\
\text { pertandingan. } \\
\text { c. Mengarahkan kepanitiaan untuk mengarsipkan } \\
\text { catatan/dokumen hasil pertandingan untuk selanjutnya } \\
\text { direkapitulasi. } \\
\text { d. Mendampingi dan mengontrol seluruh kerja kepanitiaan } \\
\text { pada setiap pertandingan. } \\
\text { e. Mengarahkan kepanitiaan untuk mengatur keamanan baik } \\
\text { pemain, official maupun suporter selama penyelenggaraan } \\
\text { turnamen. } \\
\text { f. Mengarahkan kepanitiaan untuk melakukan rekapitulasi } \\
\text { hasil pertandingan hingga penentuan tim juara group dan } \\
\text { runner up. } \\
\text { g. Mengarahkan kepanitiaan untuk mengatur dan } \\
\text { menyelenggarakan pertandingan quarter final, semi final } \\
\text { dan final. } \\
\text { h. Mendampingi peserta dalam kegiatan evaluasi kegiatan } \\
\text { turnamen. }\end{array}$ \\
\hline
\end{tabular}


Secara khusus dalam kegiatan pendampingan penyelenggaraan kegiatan turnamen terdapat beberapa hal pokok yang menjadi penekanan pada peserta pelatihan dalam kegiatan pengabdian sperti pada Tabel 3.

Tabel 3. Kegiatan pelatihan manajemen penyelenggaraan turnamen bola voli

\begin{tabular}{|c|c|c|c|}
\hline No & $\begin{array}{c}\text { Materi } \\
\text { Kegiatan }\end{array}$ & & Fokus Pendampingan \\
\hline 1 & Technical meeting & a) & $\begin{array}{l}\text { Menyiapkan berkas-berkas TM, diantaranya: Peraturan } \\
\text { Pertandingan, Daftar Hadir Peserta TM, Draft Pembagian } \\
\text { Grup dan Jadwal Silangan (dalam bentuk "Pengkodean"), } \\
\text { Contoh Berkas Pertandingan (secara khusus terdiri dari: } \\
\text { Profil Tim, Daftar Susunan Pemain dan Line Up Set). } \\
\text { Pelaksanaan TM, sesuai dengan urutan, yaitu: (1) } \\
\text { Pembahasan Perturan Pertandingan termasuk Tata Cara } \\
\text { Pengisian Berkas Pertandingan, (2) Model, Jenis dan } \\
\text { Jumlah Pembagian Grup, (3) Pembahasan Draf Jadwal } \\
\text { Pertandingan (dalam bentuk "Pengkodean Grup"), (4) } \\
\text { Bentuk Silangan Pertandingan untuk Babak I, Babk ke-II } \\
\text { dan Babak ke-III, (5) Pengundian Tim dalam Pembagian } \\
\text { Grup yang Real, dan (6) Penandatangan Berita Acara TM } \\
\text { serta Penyerahan Hasil TM sebagai Dokumen Peraturan } \\
\text { Turnamen yang Resmi dan Sah. }\end{array}$ \\
\hline 2 & $\begin{array}{l}\text { Pembuatan, } \\
\text { Penggandaan dan } \\
\text { Pengorganisasian } \\
\text { Berkas } \\
\text { Pertandingan. }\end{array}$ & $\begin{array}{l}\text { a) } \\
\text { b) } \\
\text { c) }\end{array}$ & $\begin{array}{l}\text { Pembuatan Daftar Susunan Pemain (DSP) dan Line Up } \\
\text { Set masing-masing Tim untuk setiap pertandingan. } \\
\text { Penggandaan Score Sheet untuk seluruh pertandingan. } \\
\text { Pengorganisasian Berkas Pertandingan untuk seluruh } \\
\text { pertandingan ke dalam masing-masing jepitan berkas, } \\
\text { yang terdiri dari: DSP dan Line Up Set untuk Tim A dan B } \\
\text { serta Score Sheet Pertandingan. } \\
\text { Pembuatan dan Pengorganisasian Rekapan Hasil dan } \\
\text { Perhitungan Poin Tim. } \\
\text { Pembuatan Jadwal Perwasitan (Pengawas Pertandingan, } \\
\text { Wasit 1, Wasit 2, Scorer, dan Hakim Garis) untuk seluruh } \\
\text { pertandingan. }\end{array}$ \\
\hline 3 & $\begin{array}{l}\text { Pendampingan } \\
\text { Pelaksanaan } \\
\text { Pertandingan. }\end{array}$ & $\begin{array}{l}\text { a) } \\
\text { b) }\end{array}$ & $\begin{array}{l}\text { Mengarahkan masing-masing tim untuk menempati ruang } \\
\text { ganti persiapan tim. } \\
\text { Pelaksanaan Match Meeting Coordination (Rapat } \\
\text { Koordinasi Pertandingan) untuk setiap pertandingan } \\
\text { dengan menghadirkan: Panitia, Tim Wasit, dan Official } \\
\text { Tim, dengan Agenda: (1) Pengecekan Keabsahan } \\
\text { Pemain oleh Panitia dan masing-masing Official dengan } \\
\text { sistem silang, (2) Penyerahan DSP dan Line UP Set } \\
\text { kedua Tim, (3) Pengecekan Pemain dan Nomor } \\
\text { Punggung Pemain oleh Tim wasit sesuai dengan DSP } \\
\text { yang diberikan, (4) Penentuan Waktu Time Out dan Jenis } \\
\text { Pemanasan (Tes Net) yang diinginkan oleh kedua Tim, } \\
\text { (5) Pelaksanaan Undian (Pemilihan Tempat dan/atau } \\
\text { Bola) dan (6) Persiapan Akhir Pemain untuk } \\
\text { Bertandingan. } \\
\text { Mengarahkan masing-masing official tim untuk terlebih } \\
\text { dahulu menuju ke lapangan pertandingan dan } \\
\text { mempersiapkan kebutuhan tim di masing-masing Bench } \\
\text { Pemain Tim. } \\
\text { mengatur barisan Tim Wasit (Pengawas Pertandingan, } \\
\text { Wasit 1, Wasit 2, Scorer, dan Hakim Garis) dari ruang } \\
\text { ganti menuju ke lapangan pertandingan. } \\
\text { Mengawasi proses perjalanan Perangkat dan Peserta } \\
\text { Pertandingan menuju ke lapangan pertandingan dan }\end{array}$ \\
\hline
\end{tabular}




\begin{aligned} & \hline f) $\begin{array}{l}\text { Pelaksanaan Ceremonial Pertandingan. } \\ \text { Mengatur dan Mengawasi jalannya pertandingan } \\ \text { termasuk petugas Ball Boys. }\end{array} \\ &$ g) $\begin{array}{l}\text { Pengamanan dan Pengadministrasian Hasil Pertandingan } \\ \text { kemudian di buat dalam Rekapan Hasil Pertandingan. }\end{array} \\ &$ h) Mempersiapkan Pertandingan Berikutnya. \\ & \hline\end{aligned}

Berbagai rangkaian kegiatan pelatihan selalu melibatkan mahasiswa peserta secara menyeluruh. Pelatihan dilakukan dengan sistim rolling task pada setiap pertandingan sehingga semua peserta mendapatkan kesempatan yang sama untuk bertugas baik sebagai petugas pertandingan (wasit $1 \& 2$, scorer, wasit garis), ball boys, komentator, petugas keamanan serta tugas-tugas lain yang berhubungan langsung dengan penyelenggaraan kegiatan turnamen. Seluruh kegiatan turnamen didokumentasikan secara baik dan teratur.
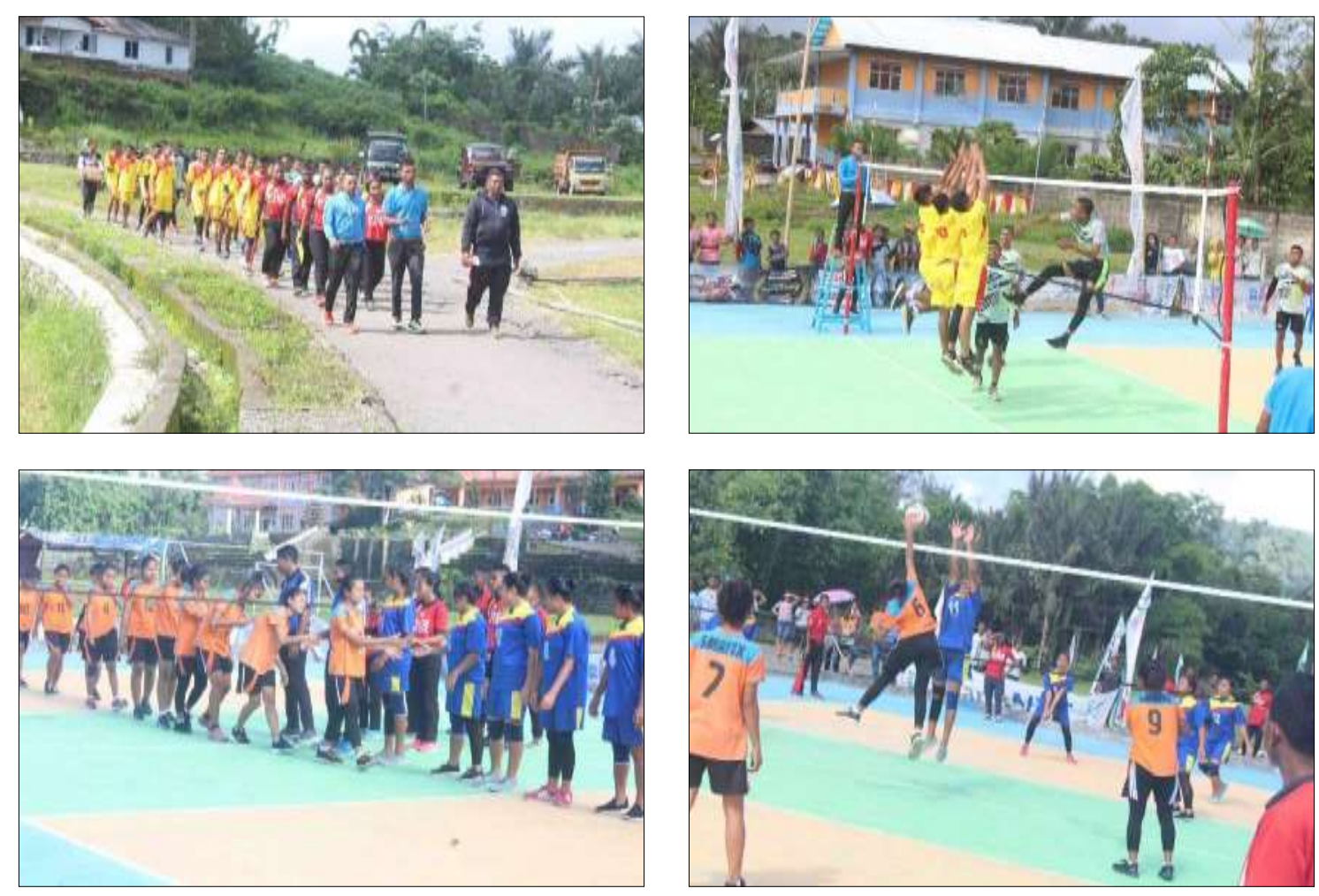

\section{Gambar 1. Kegiatan Pendampingan dan Pelatihan Manajemen Penyelenggaraan Pertandigan Bola Voli}




\section{Pembahasan}

Berdasarkan hasil pengamatan dan evaluasi yang dilakukan selama dan setelah kegiatan berlangsung, dapat disimpulkan beberapa capaian yang diperoleh dalam kegiatan pendampingan ini yakni sebagai berikut.

1. Secara keseluruhan, mahasiswa memberikan respon yang sangat baik dan bertanggung jawab dengan seluruh beban tugas yang diberikan selama masa pelatihan.

2. Mahasiswa menunjukan sikap proaktif selama kegiatan pelatiahan, hal ini terlihat dari kemampuan untuk merencanakan, melaksanakan dan mengevaluasi setiap uraian tugas yang diberikan selama penyelenggaraan turnamen.

3. Adanya peningkatan keterampilan mahasiswa dalam mengemban tugas-tugas kepanitiaan selama mengelola dan mengatur alur kegiatan penyelenggaraan turnamen baik pada tahap pembentukan kepanitiaan, tahap kerja persiapan, tahap penyelenggaraan turnamen serta evaluasi akhir.

4. Mahasiswa mengahrapkan adanya program-program pelatihan serupa untuk cabang olahraga lainnya sehingga mampu memberikan pengalaman lebih dalam hal keterampilan dalam merencanakan, mengelola dan menyelenggarakan berbagai event olahraga baik dalam skala kecil maupun skala yang lebih luas.

Hasil kegiatan pelatihan manajemen penyelenggaraan turnamen bola voli ini memberikan gambaran yang jelas bahwa mahasiswa program studi PJKR perlu mendapatkan pengalaman belajar lebih, tidak hanya secara teori di dalam kelas namun lebih dari itu harus memiliki kesempatan untuk mengimplementasikan ilmu pengetahuan yang diperoleh melalui kegiatan-kegiatan pelatihan yang berdaya guna sehingga menjadi nilai lebih yang dapat diberdayagunakan. Konsep pengembangan dan peningkatan keterampilan melalui kegiatan pelatihan seperti ini juga sejalan dengan beberapa kajian teoritik seperti yang diungkapkan oleh Lee, Kane, Gregg, \& Cavanaugh (2016: 116) bahwa kompetisi karir selalu menuntut mahasiswa untuk berpartisipasi dalam berbagai bentuk kegiatan belajar praktis (magang atau praktikum) yang relevan untuk mengimplementasikan ilmu pengetahuan dan memperoleh pengalaman bernilai. Oleh karena itu, berbagai kegiatan yang memungkinkan adanya proses aplikasi ilmu secara langsung melalui pelatihan dan pendampingan perlu untuk terus dilakukan agar memberikan pengalaman lebih bagi mahasiswa. Hal ini dikarenakan bidang ilmu keolahragaan (dalam hal ini program studi PJKR) merupakan bidang ilmu terapan yang menuntut pengetahuan dan keterampilan pada porsi penguasaan yang seimbang yang diperoleh dengan berbagai pendekatan baik di dalam maupun luar kelas (Brown, Willet, Goldfine, \& Goldfine, 2018:76).

Pelatihan dan pendampingan seperti pada kegiatan pelatihan manajemen penyelenggaraan turnamen bola voli ini, menitikberatkan pada peningkatan keterampilan 
dan pengalaman praktikal yang relevan bagi para mahasiswa Program Studi PJKR sehingga memungkinkan mereka untuk memiliki daya saing yang tinggi dikemudian hari dalam dunia kerja. Kegiatan ini juga menjadi momentum bagi mahasiswa untuk saling memberikan feedback yang berarti bagi sesama peserta sehingga memungkinkan adanya pengalaman belajar yang lebih mendalam.

Selain beberapa capaian seperti yang diuraikan pada hasil kegiatan, terdapat hal-hal positif lainnya yang diperoleh setelah mahasiswa mengikuti kegiatan pelatihan ini yakni;

1. Keterampilan mengorganisasi teman dalam kelompok (kepanitiaan).

2. Belajar disiplin waktu.

3. Kemampuan menganalisa situasi selama kegiatan sehingga dapat mengantisipasi berbagai kendala yang timbul.

4. Membangun kebiasaan kerjasama baik dengan sesama mahasiswa dalam kepanitiaan maupun dengan tim dan official peserta turnamen.

5. Belajar bertanggung jawab terhadap tugas-tugas yang diberikan.

6. Memiliki kepekaan terhadap kebutuhan tim.

7. Belajar membangun relasi baik dengan tim peserta turnamen baik pemain, pelatih, maupun official serta elemen lain yang terlibat seperti aparat kepolisian, lembagalembaga pemerintahan yang terkait baik ditingkat desa/kelurahan, kecamatan serta daerah.

\section{KESIMPULAN}

Adapun kesimpulan yang dapat dibuat dalam kegiatan pelatihan ini adalah; melalui kegiatan pelatihan ini mahasiswa belajar merencakan, menyelenggarakan dan mengevaluasi penyelenggaraan kegiatan turnamen olahraga khususnya bola voli secara baik dan bertanggungjawab. Hal ini tergambar dari beberapa hal seperti; mahasiswa memiliki respon yang baik dan bertanggung jawab selama kegiatan pelatihan, mahasiswa terlibat langsung dan proaktif dalam belajar merencanakan, melaksanakan dan mengevaluasi penyelenggaraan turnamen bola voli, serta adanya peningkatan kemampuan dan keterampilan mahasiswa dalam menyelenggarakan kegiatan turnamen bola voli.

Berdasarkan hasil pelaksanaan kegiatan pengabdian ini, adapun beberapa hal yang menjadi saran penulis adalah sebagai berikut.

1. Kegiatan pendampingan dan pelatihan manajemen pertandingan yang dilaksanakan secara langsung dalam sebuah even olahraga resmi sangat dibutuhkan oleh mahasiswa/i olahraga sebagai wadah pembelajaran real dalam mengaptualisasikan kompetensi diri. 
2. Kegiatan pendampingan dan pelatihan manajemen pertandingan hendaknya dilakukan juga pada cabang-cabang olahraga lainnya.

\section{DAFTAR PUSTAKA}

Brown, C., Willet, J., Goldfine, R., \& Goldfine, B. (2018). Sport management internships: Recommendations for improving upon experiential learning. Journal of Hospitality, Leisure, Sport \& Tourism Education, $22 \quad$ (2018) 75-81. https://doi.org/10.1016/.j.jhlste.2018.02.001.

Firmansyah, G., \& Hariyanto, D. (2019). Organisasi dan sistem pertandingan olahraga. Malang: Media Nusa Creative.

Hartmann, D., \& Kwauk, C. (2011). Sport and development an overview, critique, and reconstruction. Journal of Sport \& Social Issues 35(3):284-305. https://doi:10.1177/0193723511416986.

Lee, J. W., Kane, J. J., Gregg, E. A., \& Cavanaugh, T. (2016). Think globally, engage pedagogically: Procuring and supervising international field experiences. Journal of Hospitality, Leisure, Sport \& Tourism Education, 19,115-120. https://doi:10.1016/j.jhlste.2016.09.003.

Marwan, L., Rahmat. A.A., \& Rohyana, A. (2018). Pelatihan Pengelolaan Manajemen Event Pertandingan Olahraga Untuk Pengurus Dan Anggota Koni Kota Tasikmalaya. Jurnal Pengabdian Siliwangi, 4 (2), 179-185.

Tapo, Y.B.O. (2019). Pengembangan model latihan sirkuit pasing bawah T-Desain (SPBTdesain) bola voli sebagai bentuk aktivitas belajar siswa dalam pembelajaran PJOK untuk tingkat sekolah menengah. Ejurnal IMEDTECH-Instructional Media, Design And Technology, 3 (2), 18-34 